\title{
Health implications of torture in Pakistan
}

\author{
Mahboob Mehdi Islamabad, Pakistan
}

\section{Pakistan: background information}

The demand for a separate country for the Indian muslims resulted in the creation of Pakistan in 1947 by dividing British India. The migration of millions of people across the newly created borders of India and Pakistan resulted in the uprooting of innumerable communities and massive intercommunal massacres. This newly created country with a highly traumatised population was easily taken over by a regime which had no sympathy with the people. The ruling junta governed the country through an amalgamation of religion and politics. The human rights situation in Pakistan has had a low profile ever since the foundation of the country. The police department established during the colonial period, on the basis of the Police Act 1861 , continued in the same form and the legacy of torture inherited from the past became established in the new state of Pakistan as well. A number of further statutes were passed which justified torture and preventive detention. Torture remained a normal part of interrogation and punishment for any activity which was deemed undesirable by the ruling junta. The first constitution of Pakistan was framed in 1956. It did not improve the situation. The government continued to possess extensive arbitrary powers of arrest and detention without trial.

In October 1958 the constitution was superseded by the imposition of martial law in the country. Martial law regulations and orders were issued to govern the country. Military courts and tribunals were established with unlimited powers to arrest and try political activists. In 1962 Ayub Khan, the Chief Martial Law Administrator enforced a new constitution, which helped him to become president of the country. This constitution also was repressive in character. Resentment against this constitution developed into political agitation in 1968. To control the situation, a second series of martial laws were imposed in March 1969. The commander-in-chief of the army, General Yahya Khan, assumed power both as Chief Martial Law Administrator and as President. The Martial Law Administration started a military action in the east wing of the country aimed at suppressing the right of self-determination of the people there. The result was separation of the east wing of the country to become
Bangladesh. This situation also resulted in the replacement of General Yahya Khan by Zulfiqar Ali Bhutto, who was the majority party leader from West Pakistan.

Zulfiqar Ali Bhutto acted as a Civilian Martial Law Administrator till the enforcement of a new constitution which also failed to improve the human rights situation in Pakistan. Police atrocities, torture and repression of political opponents continued.

In July 1977 another series of martial laws were imposed on the country by the Army Chief, General Zia-ul-Haq. This was the longest-lasting and the most ruthless of the states of martial law in Pakistan. Thousands of people were tried and punished by the military courts. Punishments included the death sentence, imprisonment, life imprisonment, flogging, confiscation of property and unlimited fines. During this period rapid growth and further institutionalisation of torture occurred in Pakistan. In the name of religion, the state tried to provide a moral basis for torture.

The instances of torture and cruel punishments inflicted during this martial law regime can be summarised as follows:

(a) For the first time, under this third state of martial law, political activists were punished by whipping for political actions such as making a speech, holding a meeting, demonstrating or organising a march against the continuance of martial law.

(b) Political workers, trade unionists, women activists, lawyers and students were arrested from time to time and kept in detention without trial for months, and in some cases for years.

(c) Trials of hundreds of political activists on charges of a political nature were conducted by special, summary military courts; those being tried were invariably convicted even though the evidence against them was scant and of a most doubtful nature. Punishments consisted of long imprisonment, heavy fines and sometimes whipping.

(d) In cases where a 'wanted' political activist was not available, members of his or her family were detained to put pressure on the person sought for arrest.

(e) Detained persons were not always taken to prison but were on many occasions taken to special torture 
dens, which were operated both by the civil police and the army authorities. Reports of extensive torture carried out on political activists, including women, were not uncommon.

(f) Many of those who were kept in prison were placed in shackles and fetters and remained in isolation from others for months on end.

(g) Death sentences were awarded and executed where trials were held by military courts even though no legal evidence was available to prove the guilt of the person convicted and serious questions of jurisdiction were raised.

(h) Political detainees and convicts were not treated in accordance with ordinary prison rules.

(i) Cases have occurred where political activists were not proved guilty, but remained in prison and where activists who had been convicted were not released even though they had completed their sentence.

(j) Cases have occurred where children were detained, imprisoned and flogged.

(k) Flogging and hanging were sometimes carried out in public.

Torture is interwoven in the socio-economic matrix of Pakistan. It is seen and used as an essential instrument to maintain the survival of the system. Change in governments may bring a change in the amount of torture carried out but the institutions of torture remain intact. The laws which allow torture remain. Torture cells remain and torturers also remain. This is why the death of General Zia in a plane crash in August 1988 did not mark the end of torture in Pakistan. Torture is endemic in Pakistan but it reaches epidemic proportions from time to time.

\section{The health profession and torture}

There are two aspects to this issue in Pakistan: the involvement of health professionals in the process of torture, and care rendered to the torture victims by health professionals.

As far as the involvement of health professionals in the torture process is concerned, it is a very serious problem in Pakistan. The doctors who facilitate torture in Pakistan usually:

a) advise the torturers about the actual condition of the victim's health,

b) revive the victims sufficiently to undergo further torture.

The code of medical ethics of the Pakistan Medical and Dental Council does not mention anything about torture. Doctors who take part in the process of torture do not face any disciplinary action by the Pakistan Medical and Dental Council. In Pakistan the participation of doctors in the process of torture or cruel, inhuman and degrading punishment is usually legal: it has been made part of their duties. The following main types of abuse of clinical skills exist in Pakistan:
(1) Under the punishment by whipping ordinance of 1979 , before the execution of the punishment begins, the convict must be examined by the authorised medical officer to ensure that the carrying out of the punishment will not cause the death of the convict. If the convict is ill, the punishment must be postponed until the convict is certified by the authorised medical officer to be physically fit enough to undergo the punishment. The punishment must be carried out in the presence of the authorised medical officer at such a place as the provincial government may appoint for the purpose. If, after the punishment has begun, the authorised medical officer fears it might be going to cause the death of the convict, the punishment must be postponed until he certifies the convict to be physically fit enough to undergo the remainder of the punishment.

(2) At many interrogation centres, the person to be interrogated is examined by the doctor in order to be declared fit for interrogation.

(3) The conduct of the prison medical officer is, in most cases, highly unethical and falls far short of United Nations declarations and codes of conduct. Instead of providing standard and best possible treatment for the prisoners, the prison medical officer usually behaves as part of the prison administration and takes part im torture.

(4) Coverup activities by some doctors, such as providing false death certificates and false clinicab records of the torture victims is very common.

(5) If the court orders amputation of a hand or foot as punishment, then according to the law this will be implemented personally by an authorised medical officer.

(6) In Pakistan severe and cruel punishments can be imposed for drinking, so called illicit sexual relations and pregnancy out of wedlock. And these punishments are given after confirmation of the 'offence' by the doctor. We are of the opinion that doctors should refuse to examine such persons for confirmation of the 'offence', in order that they do not become part of cruel, inhuman or degrading punishments.

(7) I have interviewed men and women who were tortured in different torture chambers and prisons throughout Pakistan. These victims have given evidence about the participation of doctors in the process of torture. One of the victims I interviewed was a doctor: he faced a doctor who was a former classmate in the torture chamber.

The second aspect of torture as related to the health profession concerns the care of torture victims. Official medical circles in Pakistan have never recognised torture as a health-related problem. There are thousands of torture victims and their families in need of health care in Pakistan. But the training of health professionals in the various institutions of Pakistan does not bring into consideration the problem of torture and how health professionals should react to it. 


\section{Voice against torture}

The first organised and systematic effort to combat the serious problem of torture which exists in Pakistan, is 'Voice Against Torture' (VAT). VAT was formed at the beginning of 1988 as an interdisciplinary organisation for struggle against all forms of torture and for the treatment and rehabilitation of torture victims. Doctors, nurses, psychologists, physiotherapists, scientists, sociologists, lawyers, journalists, intellectuals and social workers have joined together in the network of VAT.

VAT is striving for the following aims:

1) To disseminate information among the people about the different methods of torture prevalent in society, the purposes achieved by torture and the sequelae of torture for human beings.

2) To mobilise public opinion for the eradication of all forms of torture.

3) To make doctors realise that torture is a serious challenge for the medical profession.

4) To have incorporated in the teaching courses of doctors, physiotherapists, nurses, psychologists and social workers, knowledge of torture and instruction about the methods for the treatment of torture victims.

5) To mobilise the opinion of doctors in favour of the 1975 World Medical Association's Declaration of Tokyo.

6) To convince the Pakistan Medical and Dental Council of the importance of including a clause against torture in its code of medical ethics.

7) To ensure that doctors do not participate in any procedure of torture, ie that:

a) They do not participate in coverup activities such as providing false death certificates or false clinical records of victims of torture.

b) They do not monitor torture by remaining present during any act of torture, or by declaring a person fit for torture, or by advising how far the torturers may proceed, or by reviving victims sufficiently to undergo another bout of torture.

c) They do not use their professional skills to extract information, to control prisoners or simply for punishment.

d) They provide the best quality treatment for prisoners and people in detention, and do not have a biased attitude towards them.

8) To give support to all the doctors who refuse to participate in acts of torture, so that they and their families are not victimised by various agencies of the state.

9) To collect evidence against doctors who have chosen to become instruments in the procedure of torture. To present these cases to the Pakistan Medical and Dental Council for necessary action. To take these cases to court so that these doctors may be tried for their criminal acts. To expose these doctors widely to the public via the media.

10) To mobilise opinion among members of the scientific and technical community to such an extent that they refuse to make instruments which could be used in the process of inflicting torture.

11) To conduct and participate in fact-finding missions regarding torture and other human rights violations.

12) To maintain cordial relationships with other antitorture organisations in the world. To exchange experience and to participate in joint activities and seminars etc with them.

13) To co-operate with other human rights organisations nationally and internationally. To join hands with them for the struggle to combat torture throughout the world.

14) To run the Rehabilitation and Health Aid Centre for Torture Victims (RAHAT) as a comprehensive programme.

The experience of Voice Against Torture has shown us that though countries with a high torture rate can be marked on a world map, torture itself is essentially a global phenomenon. Irrespective of faith and ideology torturers are internationally united. They co-operate with each other. They teach each other and they learn from each other. They exchange experience and technology. They even hand over people on the so called 'wanted list' to their respective governments. In such a situation those struggling against torture are in danger of becoming torture victims themselves. It is therefore very important that those struggling against torture must also unite internationally, irrespective of faith and ideology. They should increase their cooperation. They should teach each other and learn from each other. They should exchange experience and technology of the struggle against torture. They should plan measures for the protection of persons involved in anti-torture work in high risk areas. Such protection is important for the smooth, efficient and safe functioning of anti-torture organisations in high-risk areas.

\section{RAHAT}

Considering the fact that torture victims need specialised care and that such special care is not available in ordinary hospitals, VAT has established RAHAT in Islamabad. Doctors, psychiatrists, psychologists, nurses and social workers experienced in the care of torture victims provide services at RAHAT. The staff of RAHAT work as a team to assess and treat the multidimensional problems of torture victims.

- RAHAT is the only centre of its kind in South Asia where anyone suffering from the effects of torture can come for treatment.

- There is no discrimination of age, sex, religion, ideology, political affiliation, nationality or ethnic origin for treatment at RAHAT. 
- The treatment programme at RAHAT aims to provide the medical, psychological and social rehabilitation of torture victims and their families.

- Treatment at RAHAT is provided free of charge.

- Doctors, other health professionals, hospitals and all types of organisations can refer torture victims to RAHAT for treatment.

- RAHAT is also engaged in research and educational work for the purpose of combatting torture. It provides necessary information on different aspects of torture to health professionals, lawyers, human rights activists and other concerned persons.

At RAHAT we see the advantages and disadvantages of having a centre for the treatment of torture victims in the country where the torture was inflicted on those victims. In centres located in other countries only those victims can be treated who decide to leave their country and succeed in reaching foreign countries. These victims comprise a very small percentage of the total victims in need of health care. Treating torture victims in their own country means that the maximum number of torture victims can come to the centre and can feel comfortable, as they remain in the atmosphere of their own culture. Usually there is no need for interpreters and the stress of being in exile is also not there. The main disadvantage of indigenous centres is the security risk faced both by the therapist and the victim.

The following measures can reduce the risk to the indigenous centres located in the high-risk areas.

(1) Support from the masses, from the maximum number of human rights organisations, from different representative organisations and different political parties throughout the country. The centre itself should not be affiliated to any political party.

(2) Recognition by the UN and relevant affiliated organisations.

(3) Support from the different anti-torture organisations throughout the world.

(4) Support from the different human rights organisations throughout the world.

(5) Participation in international seminars etc.

(6) Wide coverage in the national and international media.

Mahboob Mehdi, MBBS, is Medical Director of RAHAT-VAT, Islamabad, Pakistan. 